\title{
Heterologous Expression of a Putative ClpC Chaperone Gene Leads to Induction of a Host Metabolite
}

\author{
Jana Braesel $^{\circledR a}$ and Alessandra S. Eustáquio ${ }^{\circledR *, a}$ \\ ${ }^{a}$ Department of Medicinal Chemistry and Pharmacognosy and Center for Biomolecular Sciences, \\ College of Pharmacy, University of Illinois at Chicago, 900 South Ashland Ave., 60607 Chicago-IL, USA
}

\begin{abstract}
Genome mining provides exciting opportunities for the discovery of natural products. However, in contrast to traditional bioassay-guided approaches, challenges of genome mining include poor or no expression of biosynthetic gene clusters (BGCs). Additionally, given that thousands of BGCs are now available through extensive genome sequencing, how does one select BGCs for discovery? Synthetic biology techniques can be used for BGC refactoring and activation, whereas resistancegene-directed genome mining is a promising approach to discover bioactive natural products. Here we report the selection of a BGC by applying a resistance-gene-directed approach, cloning of the silent BGC from Micromonospora sp. B006, promoter exchange, and heterologous expression in Streptomyces coelicolor M1152. While we have yet to identify the encoded compound, we unexpectedly observed induction of a host metabolite, which we hypothesize is due to the presence of a caseinolytic protease $\mathrm{C}(\mathrm{ClpC})$ chaperone gene in the $\mathrm{BGC}$, suggesting that $\mathrm{ClpC}$ chaperones may be used for BGC activation.
\end{abstract}

Keywords: Clp protease, Clp ATPase, Clp chaperone, genome mining, gene activation, natural product, antibiotic

\section{Introduction}

Natural products are an exceptional source of drug leads. For instance, the vast majority of antibiotics and anticancer agents in the clinic today are natural products or derivatives thereof. Given the rise of drug resistance, there is an urgent need to discover new drugs, and natural products have proven to be a reliable source. ${ }^{1}$

In spite of already being prolific sources, whole genome sequencing has shown that the biosynthetic potential of microorganisms has been underestimated based on the small number of compounds that are produced by each organism under routine laboratory growth conditions. ${ }^{2,3}$ In bacterial genomes, genes for the biosynthesis of natural products are usually co-localized in so-called biosynthetic gene clusters (BGCs). With the fast developments in genome sequencing, public databases now contain thousands of orphan BGCs, that is, BGCs for which the corresponding compound is unknown. Thus, genome mining is a promising approach for the discovery of new natural products. ${ }^{4}$ However, in contrast to traditional bioassay-guided discovery, challenges of genome mining include the fact that some BGCs are

*e-mail: ase@uic.edu poorly or not at all expressed under a particular laboratory growth condition (so-called "silent" BGCs), preventing compound identification and isolation. Additionally, given the wealth of BGCs available, how does one select BGCs for discovery?

Genetic engineering and synthetic biology approaches can help with BGC activation. For example, promoter replacements have been shown to lead to the activation of silent BGCs. ${ }^{5}$ Heterologous expression has also been used as an alternative approach to the genetic engineering of native producers. ${ }^{6}$ Moreover, resistance-gene-directed genome mining is a promising approach to discover bioactive natural products. ${ }^{7-9}$ Resistance-gene-directed genome mining relies on the observation that most antibiotic BGCs contain not only genes encoding enzymes to catalyze antibiotic biosynthesis, but also regulatory genes and resistance genes that prevent self-killing. Selfresistance mechanisms include export pumps, antibioticmodifying enzymes, and target modification. ${ }^{10}$ In the case of self-resistance genes that encode target modification, the resistance gene already gives an indication of the antibiotic target, the reason this approach has also been termed target-directed genome mining. ${ }^{7}$ For instance, the BGC for the gyrase inhibitor novobiocin contains a gene 
encoding a gyrase subunit that was shown to be resistant to novobiocin. ${ }^{11}$ Similarly, the BGC for the proteasome inhibitor salinosporamide A contains a gene encoding a salinosporamide-resistant proteasome subunit. ${ }^{12}$ The resistance gene present in the BGC is in addition to a housekeeping copy present elsewhere in the genome. Duplication and differential regulation are presumably important because the resistant copy may be less active than the housekeeping one; in other words, resistance may have evolved at the expense of a loss in enzyme activity. Thus, the target-directed genome mining approach looks for duplication of housekeeping, essential genes, and the association of one of the duplicated copies with a natural product BGC. ${ }^{7,8}$

In the examples mentioned above the compounds and their modes of action were known before the BGC was identified. With the advancements in genome sequencing, bioinformatics, and synthetic biology, the scientific community is now in a position to potentially identify BGCs that encode compounds for a specific target of interest before the compound is even isolated, as has recently been demonstrated. ${ }^{7,9}$

One of the targets we are interested in is the caseinolytic protease (Clp) system. Clp proteases have been identified as promising antibacterial targets. ${ }^{13}$ They play a central role in a great number of processes ranging from general maintenance of protein quality to tight control of key regulatory elements such as transcription factors with impact on stress survival, virulence, and antibiotic resistance. ${ }^{14}$ The Clp complex is composed of a proteolytic core (assembled from 14 caseinolytic protease $\mathrm{P}(\mathrm{ClpP})$ subunits) and various adenosine triphosphatase (ATPase) orthologs (e.g., caseinolytic proteases X, C or A (ClpX, ClpC or ClpA, respectively)). ${ }^{15}$ In association with the proteolytic core, the Clp ATPases are responsible for recognition, unfolding, and translocation of the substrate into the $\mathrm{ClpP}$ degradation chamber. ${ }^{16}$ Independently of ClpP, they support the refolding process of aberrant proteins. In Mycobacterium tuberculosis and other related Actinobacteria, $\mathrm{ClpP}, \mathrm{ClpX}$, and $\mathrm{ClpC}$ are essential enzymes. ${ }^{14} \mathrm{An}$ interesting finding in recent years was the discovery of several new types of antibiotics, such as cyclomarin A, lassomycin and ecumicin, which kill bacteria by interfering with the function of Clp protease subunit ClpC1. ${ }^{17-21}$ They show potent activity against multidrugresistant M. tuberculosis strains, as well as drug-sensitive strains. ${ }^{17,18,20,22}$

Here we report the selection of a putative $\mathrm{ClpC}$-containing BGC from Micromonospora sp. strain B006, its cloning, promoter exchange, and heterologous expression in Streptomyces coelicolor M1152, which unexpectedly led to induction of a host metabolite.

\section{Experimental}

\section{General experimental procedures}

All chemicals were acquired from Sigma-Aldrich, Alfa Aesar, MP Biomedicals, VWR, and Fisher Scientific. Solvents were of high performance liquid chromatography (HPLC) grade or higher. Restriction enzymes were purchased from New England Biolabs. Oligonucleotide primers were synthesized by Sigma-Aldrich. Molecular biology procedures were carried out according to the manufacturers' instructions (Ambion, Invitrogen, New England Biolabs, Thermo Fisher Scientific, Sigma-Aldrich, Qiagen, Zymo Research) or as described below.

\section{Cultivation conditions}

Micromonospora sp. B006 was routinely cultivated at $30{ }^{\circ} \mathrm{C}$ on International Streptomyces Project 2 (ISP2) medium $(0.4 \%$ yeast extract, $1 \%$ malt extract, $0.4 \%$ dextrose, $\mathrm{pH} 7.3$, and $2 \%$ agar for solid medium). To isolate genomic deoxyribonucleic acid (DNA), strain B006 was cultivated in a 1:1 mixture of tryptic soy broth (TSB) medium (3\% tryptic soy broth) and yeast extractmalt extract (YEME) medium $(0.3 \%$ yeast extract, $0.5 \%$ peptone, $0.3 \%$ malt extract, $1 \%$ glucose, $34 \%$ sucrose, $5 \mathrm{mM} \mathrm{MgCl}_{2}$ ) for two days at $30^{\circ} \mathrm{C}$ and $200 \mathrm{rpm}$.

Streptomyces coelicolor M1152 was maintained on mannitol soya flour (MS) solid medium (20 g soy flour, $20 \mathrm{~g}$ mannitol, and $20 \mathrm{~g}$ agar in $1 \mathrm{~L}$ tap water) ${ }^{23}$ To isolate genomic DNA, S. coelicolor M1152 wild-type strain and exconjugants were cultivated in TSB liquid medium for 3 days at $30{ }^{\circ} \mathrm{C}$ and $200 \mathrm{rpm}$. To obtain spores for conjugation, S. coelicolor M1152 was cultivated at $30^{\circ} \mathrm{C}$ on MS solid medium for two to three weeks.

Escherichia coli strains were cultivated in lysogeny broth (LB) medium supplemented with the appropriate antibiotics. The following antibiotics were used as selection markers: kanamycin $\left(50 \mu \mathrm{g} \mathrm{mL}^{-1}\right)$, chloramphenicol $\left(25 \mu \mathrm{g} \mathrm{mL} L^{-1}\right)$, and nalidixic acid $\left(25 \mu \mathrm{g} \mathrm{mL}^{-1}\right)$.

Construction of capture vector pJB005EL for transformationassociated recombination (TAR) cloning in yeast

The 119 base pair (bp) double-stranded DNA ( $d s$ DNA) fragments were designed as shown in Figure 1 (5'-CTCGAGGCAGGATCACCGTGCAGGAGGCGA CGGCTCGCATCGCTGACCTGGTCACCGGATCCCC AACCTTGGTCAGTCATGACCCACGAGCGTTAGAA GCAGGACTGTCTCGCCATATG-3'; restriction sites are underlined; C: cytosine, T: thymine, G: guanine and 
A: adenine) and synthesized by GenScript. The two restriction sites $\mathrm{XhoI}$ and $\mathrm{NdeI}$ were used to clone the synthetic DNA fragment into the same sites of the vector pCAP03-acc(3)IV yielding the capture vector pJB005EL. Prior to direct TAR cloning, the capture vector was digested with BamHI.

Cloning of the non-ribosomal peptide synthetase (NRPS)polyketide synthase (PKS) gene cluster by direct capture from genomic DNA using TAR

High molecular weight genomic DNA was isolated from Micromonospora sp. B006 using the Blood \& Cell Culture DNA Midi Kit (Qiagen). Direct TAR cloning of the NRPS-PKS gene cluster from genomic DNA was carried out using a previously reported protocol with minor modifications. ${ }^{7}$ Solutions used were prepared according to Kouprina and Larionov. ${ }^{24}$ Spheroplast cells were prepared using Zymolyase (100T equivalent; Zymo Research) at a final concentration of $1 \mathrm{mg} \mathrm{mL}^{-1}$. The Zymolyase reaction was incubated for $50 \mathrm{~min}$ at $30^{\circ} \mathrm{C}$ and $70 \mathrm{rpm}$. A total of $3 \mu \mathrm{g}$ of genomic DNA and $1 \mu \mathrm{g}$ of the linearized capture vector were used for yeast transformation. The transformed spheroplasts were mixed with $9 \mathrm{~mL}$ of synthetic tryptophan drop-out (SD-Trp) top agar (containing 1.5\% agar) at $55^{\circ} \mathrm{C}$ and overlaid on SD-Trp containing 5-fluoroorotic acid (FOA) agar (containing 2\% agar). The plates were incubated for 6 days at $30{ }^{\circ} \mathrm{C}$. Transformants were picked and transferred onto new SD-Trp-FOA agar plates and incubated for 3 days at $30{ }^{\circ} \mathrm{C}$. Genomic DNA extraction from yeast was carried out using single-tube lithium acetate-sodium dodecyl sulfate (SDS) lysis. ${ }^{25}$ A single colony of each transformant was suspended in $100 \mu \mathrm{L}$ of a solution containing $200 \mathrm{mM}$ lithium acetate and 1\% SDS.
The reactions were vortexed and then incubated for $5 \mathrm{~min}$ at $70^{\circ} \mathrm{C}$. Subsequently, $300 \mu \mathrm{L}$ of absolute ethanol (molecular biology grade) was added for DNA precipitation. Samples were mixed by inverting, incubated for $15 \mathrm{~min}$ at $-20^{\circ} \mathrm{C}$ and then centrifuged for $10 \mathrm{~min}$ at $15,000 \mathrm{rpm}$. The pellets were then washed with $70 \%$ ethanol. After the pellets were dried, they were resuspended in $100 \mu \mathrm{L}$ sterile distilled water. The transformants were screened by polymerase chain reaction (PCR) using primer pairs oJB7/ oJB8 and oJB9/oJB10, respectively (Table 1). The $20 \mu \mathrm{L}$ reactions consisted of $0.2 \mathrm{mM}$ of each deoxynucleoside triphosphate (dNTP), 3\% dimethylsulfoxide (DMSO), $0.5 \mu \mathrm{M}$ (each) primer, and $0.02 \mathrm{U}_{\mu \mathrm{L}^{-1}}$ Phusion HighFidelity DNA polymerase (Thermo Fisher Scientific) in the buffer supplied with the enzyme and using the following thermal cycling parameters: $30 \mathrm{~s}$ at $98^{\circ} \mathrm{C} ; 35$ cycles of $98{ }^{\circ} \mathrm{C}$ for $10 \mathrm{~s}, 62.8 / 65^{\circ} \mathrm{C}$ for $20 \mathrm{~s}$, and $72{ }^{\circ} \mathrm{C}$ for $30 \mathrm{~s}$; and a terminal extension for $5 \mathrm{~min}$ at $72{ }^{\circ} \mathrm{C}$. Plasmid pJB005EL was used as negative control. PCR positive clones were then grown in $4 \mathrm{~mL}$ SD-Trp liquid medium for $35 \mathrm{~h}$ at $30{ }^{\circ} \mathrm{C}$ and $220 \mathrm{rpm}$. Cells were lysed using Zymolyase (100T equivalent) at $30^{\circ} \mathrm{C}$ for $2 \mathrm{~h}$. Plasmids were extracted following the protocol of Tang et al. ${ }^{7}$ and then transferred into $E$. coli $\mathrm{DH} 5 \alpha$ by electroporation. The plasmids were purified from kanamycin-resistant $E$. coli clones using ZR BAC DNA Miniprep kit (Zymo Research) and then confirmed by restriction digest with BamHI. The vector containing the NRPS-PKS hybrid gene cluster was designated as pJB007EL.

\section{Promoter replacement}

To ensure transcription in S. coelicolor M1152, the native promoter was replaced with the constitutive promoter (a)

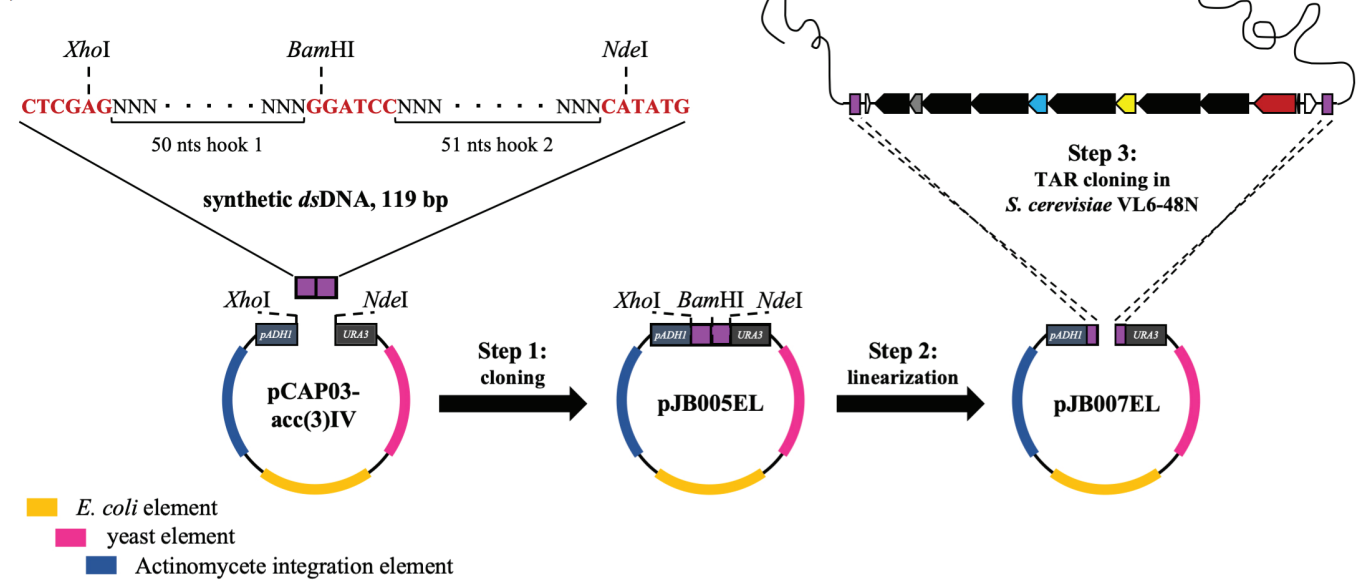

(b)

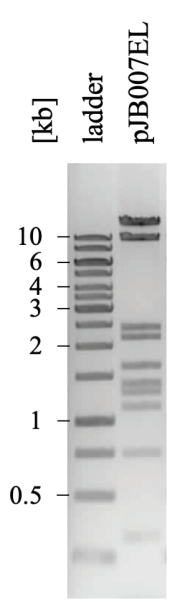

Figure 1. Cloning of the ClpC-containing BGC. (a) Schematic representation of cloning directly from genomic DNA using TAR in yeast; (b) confirmation of obtained clones by restriction digest with BamHI. Expected fragments: 319, 740, 1,130, 1,290, 1,385, 1,630, 2,172, 2,397, 10,129, and 16,868 bp. 
Table 1. Oligonucleotide primers used during this study

\begin{tabular}{|c|c|}
\hline Primer $^{\mathrm{a}}$ & Sequence (5' to 3') \\
\hline P1_apra_f & ATG AGC TCA GCC AAT CGA C \\
\hline P1_ORF_apra_f & CCG CCG CCT TTC GAT CAC GCC TTC GCC GCC CGA ACT CGG CAT GAG CTC AGC CAA TCG AC \\
\hline P2_apra_r & GAT GTC ACG CTG AAA ATG C \\
\hline P3_apra_ermE*_f & 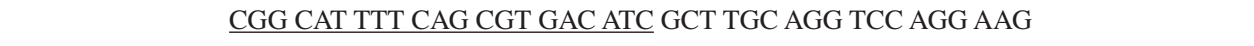 \\
\hline P4_apra_ermE*_f & ACC GCT GGA TCC TAC CAA C \\
\hline P4_ORF_apra_ermE*_r & 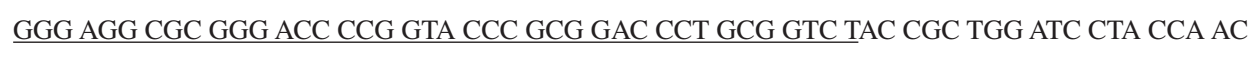 \\
\hline oJB7 & CAC TCC ATC GTA TCC GTA TTC C \\
\hline oJB8 & GTT GAG ACT ACG CAT CGA CC \\
\hline oJB9 & AGC GTA CCG AGC AGC TTG C \\
\hline oJB10 & CTC TTC GCA ATG TCA ACA GTA CC \\
\hline oJB71 & GCA GGT CGT CGC GTT CAG \\
\hline oJB72 & CTC CAC GTC AGC CTG CCA \\
\hline oJB76 & AGC ACT TCG ATC GTG TCG \\
\hline oJB77 & GCT CCT TGG ACG ACT TGA \\
\hline oJB78 & CAC CAC CAC GTT CGC AAT C \\
\hline oJB79 & GGT TGG TTA CCG ACG ACG \\
\hline oJB82 & AGT GCG GTA GCA CCG CTC \\
\hline oJB83 & ACG CGG ATC TCT TCG CAC \\
\hline oJB184 & AGG CCC TTC GGG GTA CTC G \\
\hline oJB185 & GTG TTG CCG ACT TTC GTG ACG \\
\hline
\end{tabular}

averhangs are underlined. A: adenine; T: thymine; G: guanine; C: cytosine.

ermE $^{* 26,27}$ using $\lambda$-Red-mediated recombination ${ }^{28-30}$ (Figure 2). Primer pair P1_apra_f/P2_apra_r (Table 1) was used to amplify the apramycin resistance gene from vector pIJ773, ${ }^{31}$ while primers P3_apra_ermE*_f and P4_apra_ ermE*_r were used to amplify the promoter ermE $^{*}$ from vector pUWL201..$^{32}$ The $100 \mu \mathrm{L}$ PCR reactions consisted of $0.2 \mathrm{mM}$ of each dNTP, $3 \%$ DMSO, $0.25 \mu \mathrm{M}$ of each primer, and $1 \mathrm{U} \mu \mathrm{L}^{-1}$ Phusion High-Fidelity DNA polymerase in $\mathrm{HF}$ reaction buffer supplied with the enzyme. Thermocycling parameters were: initial denaturation for $1 \mathrm{~min}$ at $98{ }^{\circ} \mathrm{C}$; amplification: 30 cycles $\left(98^{\circ} \mathrm{C}\right.$ for $10 \mathrm{~s}, 62^{\circ} \mathrm{C}$ for $30 \mathrm{~s}$, $72{ }^{\circ} \mathrm{C}$ for $30 \mathrm{~s}$ ); and terminal hold for $5 \mathrm{~min}$ at $72{ }^{\circ} \mathrm{C}$. The two obtained PCR fragments (936 bp apr ${ }^{\mathrm{R}}, 217 \mathrm{bp} \mathrm{PermE*}$ ) were purified using QIAquick PCR purification kit (Qiagen) and then digested with $D p n \mathrm{I}$ for $2 \mathrm{~h}$ at $37^{\circ} \mathrm{C}$. Subsequently, the purified PCR fragments were ligated by overlap extension (OE) PCR using primers P1_ORF_apra_f and P4_ORF_apra_ermE*_r (Table 1). The 50- $\mu \mathrm{L}$ reaction consisted of the two purified DNA fragments in equimolar amounts (10 ng of $a p r^{\mathrm{R}}, 4 \mathrm{ng}$ of PermE*), $0.2 \mathrm{mM}$ of each dNTP, $3 \%$ DMSO, and $1 \mathrm{U}_{\mu} \mathrm{L}^{-1}$ Phusion High-Fidelity DNA polymerase in $\mathrm{HF}$ reaction buffer supplied with the enzyme. Thermocycling conditions were initial denaturation: $60 \mathrm{~s}$ at $98^{\circ} \mathrm{C}$; amplification: 3 cycles $\left(98^{\circ} \mathrm{C}\right.$ for $10 \mathrm{~s}, 70^{\circ} \mathrm{C}$ for
$30 \mathrm{~s}, 72^{\circ} \mathrm{C}$ for $90 \mathrm{~s}$ ). Subsequently, $0.25 \mathrm{mM}$ of each primer were added to the reaction. Thermocycling parameters were initial denaturation for $60 \mathrm{~s}$ at $98{ }^{\circ} \mathrm{C}$; amplification: 30 cycles $\left(98^{\circ} \mathrm{C}\right.$ for $10 \mathrm{~s}, 63.5^{\circ} \mathrm{C}$ for $30 \mathrm{~s}, 72^{\circ} \mathrm{C}$ for $90 \mathrm{~s}$ ); and terminal hold for $5 \mathrm{~min}$ at $72{ }^{\circ} \mathrm{C}$. Subsequently, the 1,233 bp PCR fragment was purified using the QIAquick gel extraction kit (Qiagen). The primers P1_ORF_apra_f and P4_ORF_apra_ermE*_r introduced two $40 \mathrm{bp}$ overhangs for $\lambda$-Red recombination. In parallel, plasmid pJB007EL was transferred into E. coli BW25113/pIJ790 by electroporation. Since the plasmid pIJ790 is temperature sensitive, all incubation steps were performed at $30{ }^{\circ} \mathrm{C}$. Positive clones were confirmed by restriction digest with BamHI. E. coli BW25113/pIJ790/pJB007EL was grown in LB supplemented with kanamycin and chloramphenicol at $30{ }^{\circ} \mathrm{C}$ and $200 \mathrm{rpm}$ until an optical density at $600 \mathrm{~nm}$ $\left(\mathrm{OD}_{600}\right)$ of 0.4 was reached. Then $10 \mathrm{mM}$ L-arabinose was added to induce the $\lambda$-Red genes and the culture was incubated for an additional $30 \mathrm{~min}$. The cells were washed twice with ice-cold $10 \%$ glycerol and resuspended in $1 \mathrm{~mL}$ $10 \%$ glycerol after centrifugation. Electro-competent cells $(50 \mu \mathrm{L})$ were transformed with $100 \mathrm{ng}$ purified OE-PCR product. Shocked cells were incubated in $1 \mathrm{~mL} \mathrm{LB}$ at $37{ }^{\circ} \mathrm{C}$ for $1 \mathrm{~h}$ and plated on LB containing apramycin. 


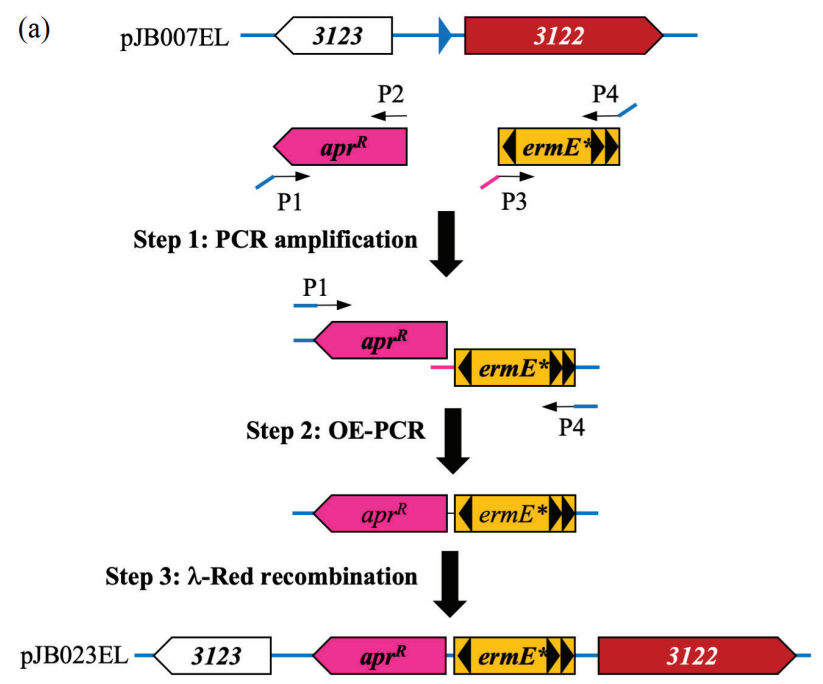

(b)

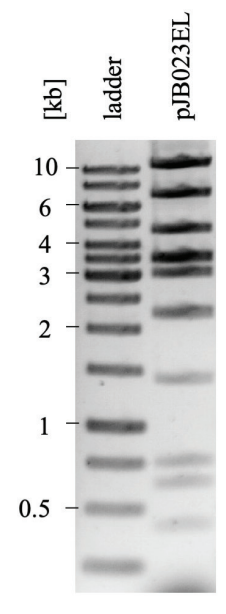

Figure 2. Promoter replacement. (a) Schematic representation of the promoter replacement design; (b) confirmation of obtained clones by restriction digest with SacI. Expected fragments: 411, 627, 752, 1,419, 2,245, 3,070, 3,546, 3,574, 4,774, 7,263, and 11,307 bp. Triangles indicate promoter sequences.

Apramycin-resistant clones were grown for $6 \mathrm{~h}$ at $37^{\circ} \mathrm{C}$ and $200 \mathrm{rpm}$. Subsequently, plasmids were isolated using ZR Plasmid Miniprep kit (Zymo Research) and confirmed by restriction digest with $S a c$ I after passage into $E$. coli DH5 $\alpha$. The plasmid containing the NRPS-PKS hybrid gene cluster under control of the promoter $\mathrm{ermE}^{*}$ was designated as pJB023EL.

\section{Heterologous expression of the NRPS-PKS gene cluster}

The plasmid pJB023EL was transferred into $S$. coelicolor M1152 by conjugation from $E$. coli ET12567/pUZ8002 as described by Kieser et al..$^{23}$ Apramycin-resistant colonies were streaked on MS plates containing apramycin and nalidixic acid until pure cultures were obtained. Genomic DNA was isolated using GenElute ${ }^{\mathrm{TM}}$ Bacterial Genomic DNA kit (Sigma-Aldrich). Gene cluster integration was confirmed by PCR with primer pair oJB71/oJB72 (Table 1) in reactions containing $0.2 \mathrm{mM}$ each $\mathrm{dNTP}, 3 \%$ DMSO, $0.2 \mu \mathrm{M}$ (each) primer, and 1.25 U DreamTaq Green DNA polymerase (Thermo Fisher Scientific) in the buffer supplied with the enzyme, in a total volume of $20 \mu \mathrm{L}$. Thermocycling conditions were initial denaturation: $3 \mathrm{~min}$ at $95{ }^{\circ} \mathrm{C}$; amplification: 35 cycles $\left(95^{\circ} \mathrm{C}\right.$ for $30 \mathrm{~s}, 72{ }^{\circ} \mathrm{C}$ for $20 \mathrm{~s}$, $72{ }^{\circ} \mathrm{C}$ for $60 \mathrm{~s}$ ); terminal extension: $5 \mathrm{~min}$ at $72{ }^{\circ} \mathrm{C}$. Genomic DNA isolated from the wild-type strain was used as negative control. Plasmid pJB023EL served as positive control.

\section{Fermentation and metabolite analysis}

For heterologous expression, $50 \mathrm{~mL}$ TSB liquid medium was inoculated with $400 \mu \mathrm{L}$ of a frozen stock of S. coelicolor M1152 wild-type strain and exconjugants, respectively. Frozen stocks were prepared with mycelium from 3 days-old TSB liquid cultures by adding glycerol to $20 \% \mathrm{v} / \mathrm{v}$ final concentration followed by storage at $-80^{\circ} \mathrm{C}$. The seed cultures were incubated for 3 days at $30{ }^{\circ} \mathrm{C}$ and $200 \mathrm{rpm}$. Subsequently, $5 \% \mathrm{v} / \mathrm{v}$ of these seed cultures were used to inoculate $50 \mathrm{~mL}$ of chemically defined medium (CDM) (30 g glucose, $6 \mathrm{~g}$ sodium citrate, $6 \mathrm{~g} \mathrm{L-proline,}$

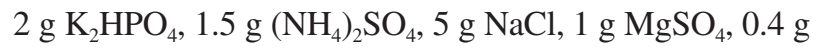
$\mathrm{CaCl}_{2}, 0.2 \mathrm{~g} \mathrm{Fe}_{2} \mathrm{SO}_{4} \cdot 7 \mathrm{H}_{2} \mathrm{O}$, and $0.1 \mathrm{~g} \mathrm{ZnSO}_{4} \cdot 7 \mathrm{H}_{2} \mathrm{O}$ in $1 \mathrm{~L}$ distilled water, $\mathrm{pH} 7.2)^{33}$ in a $250 \mathrm{~mL}$ Erlenmeyer flask. The production cultures were incubated at $30{ }^{\circ} \mathrm{C}$ and $200 \mathrm{rpm}$. After 7 days, 5\% activated Diaion HP-20 resin (Alfa Aesar) was added to the production cultures. The HP-20 resin was activated prior to use by soaking in methanol and then rinsing thoroughly with distilled water. The production cultures were incubated for an additional $24 \mathrm{~h}$ at $30^{\circ} \mathrm{C}$ and $200 \mathrm{rpm}$. The $\mathrm{pH}$ of the production fermentations was then adjusted to 4 with acetic acid. Subsequently, the cultures were harvested by centrifugation. The supernatant was decanted and the cell/resin pellet was extracted three times, each with $20 \mathrm{~mL}$ methanol. After removing the solvent under reduced pressure, the crude extracts were dissolved in methanol for HPLC and liquid chromatography (LC)-mass spectrometry (MS) analyses.

HPLC analysis was performed on an Agilent 1260 Infinity system equipped with a Kinetex ${ }^{\circledR} \mathrm{C} 18$ column $(150 \times 4.6 \mathrm{~mm}, 5 \mu \mathrm{m}$ particle size, $100 \AA$ pore size, Phenomenex ${ }^{\circledR}$ ). Solvent A was $0.1 \% \mathrm{v} / \mathrm{v}$ trifluoroacetic acid (TFA) in water, and solvent $B$ was acetonitrile. The solvent gradient was: initial hold at $10 \%$ B for $1 \mathrm{~min}$, linear gradient from 10 to $50 \%$ B within 34 min, followed by another linear gradient from 50 to $100 \%$ B within 15 min, and held for $4 \mathrm{~min}$, at a flow rate of $1.0 \mathrm{~mL} \mathrm{~min}{ }^{-1}$. The detection 
wavelength range was $200-600 \mathrm{~nm}$; chromatograms were extracted at $\lambda=210,254,280,310,410$, and $580 \mathrm{~nm}$.

MS and MS/MS analyses were performed on a Finnigan LCQ Advantage MAX mass spectrometer system (Thermo Electron Corporation) in positive mode and a Hewlett Packard series 1050 HPLC, equipped with a Kinetex ${ }^{\circledR}$ $5 \mu \mathrm{m} \mathrm{C18} 100 \AA$ A-column $(150 \times 4.6 \mathrm{~nm}, 5 \mu \mathrm{m}$ particle size, Phenomenex ${ }^{\circledR}$ ), at a flow rate of $1 \mathrm{~mL} \mathrm{~min}^{-1}$. Solvent A was $0.02 \% \mathrm{v} / \mathrm{v}$ formic acid in water, and solvent B was $0.02 \% \mathrm{v} / \mathrm{v}$ formic acid in acetonitrile. The gradient was: initial hold at $20 \%$ B for 1 min, linear gradient from 20 to $50 \% \mathrm{~B}$ within $20 \mathrm{~min}$, followed by another linear gradient from 50 to $100 \% \mathrm{~B}$ within $1 \mathrm{~min}$, and held for $3 \mathrm{~min}$. The detection wavelength range was $410 \mathrm{~nm}$. The detection mass range was 200 to 2,000 $\mathrm{Da}$ (positive mode).

\section{Transcript analysis}

S. coelicolor M1152 wild-type strain and exconjugant 2 were cultivated in $50 \mathrm{~mL}$ CDM liquid medium for 7 days at $30{ }^{\circ} \mathrm{C}$ and $200 \mathrm{rpm}$. Two-mL samples were taken on days 3,5 , and 7 . The cells were collected by centrifugation and stored at $-20^{\circ} \mathrm{C}$. Total ribonucleic acid (RNA) was isolated using the RiboPure ${ }^{\mathrm{TM}}$-Bacteria kit (Ambion). Cell lysis was obtained by homogenization using a Mini-Beadbeater ${ }^{\mathrm{TM}}$ (Biospec products) (5 cycles of $30 \mathrm{~s}$ ). DNaseI treatment was carried out for $4 \mathrm{~h}$ using TURBO DNA-free ${ }^{\mathrm{TM}} \mathrm{kit}$ (Ambion). The absence of genomic DNA in the samples was confirmed by PCR using 16S ribosomal RNA (rRNA) primers oJB184 and oJB185 (Table 1). The 20- $\mu$ L reactions consisted of $0.2 \mathrm{mM}$ of each dNTP, $3 \%$ DMSO, $0.25 \mu \mathrm{M}$ of each primer, and 1.25 U DreamTaq DNA polymerase (Thermo Fisher Scientific) in reaction buffer supplied with the enzyme. Thermocycling parameters were: initial denaturation for $2 \mathrm{~min}$ at $95^{\circ} \mathrm{C}$; amplification: 30 cycles $\left(95^{\circ} \mathrm{C}\right.$ for $30 \mathrm{~s}, 60^{\circ} \mathrm{C}$ for $30 \mathrm{~s}, 72^{\circ} \mathrm{C}$ for $60 \mathrm{~s}$ ); and terminal hold for 5 min at $72{ }^{\circ} \mathrm{C}$. Afterwards, complementary DNA (cDNA) synthesis was carried out with 250 ng RNA by using the SuperScript ${ }^{\circledR}$ IV First-Strand cDNA synthesis system (Invitrogen). A portion of the first-strand reaction $(1 \mu \mathrm{L})$ was used as template in subsequent PCRs. For the conditions for the amplification of MicB006_3120 (primer pair oJB71/oJB72), see above. The $20-\mu \mathrm{L}$ reactions to amplify the cDNAs of MicB006_3113 (primer pair oJB78/ oJB79), MicB006_3116 (primer pair oJB82/oJB83) and MicB006_3122 (primer pair oJB76/oJB77) consisted of $0.2 \mathrm{mM}$ of each dNTP, $1 \times$ Q5 High GC enhancer (New England Biolabs), $0.5 \mu \mathrm{M}$ of each primer, and $0.02 \mathrm{U}_{\mu \mathrm{L}^{-1}}$ Q5 High-Fidelity DNA polymerase (New England Biolabs) in Q5 reaction buffer supplied with the enzyme. The following thermal cycling conditions were used: $30 \mathrm{~s}$ at $98^{\circ} \mathrm{C} ; 30$ cycles of $98^{\circ} \mathrm{C}$ for $10 \mathrm{~s}, 67.7 / 68.9 / 65^{\circ} \mathrm{C}$ for $10 \mathrm{~s}$, and $72{ }^{\circ} \mathrm{C}$ for $30 \mathrm{~s}$; and a terminal hold for $2 \mathrm{~min}$ at $72{ }^{\circ} \mathrm{C}$.

\section{Results and Discussion}

\section{Resistance-gene-directed gene cluster selection}

We have recently sequenced the complete genome of Micromonospora sp. strain B006 and shown that the 7-Mb genome encodes 16 BGCs, eleven of which remain orphan. ${ }^{34}$ We were particularly intrigued by an NRPS-type I PKS gene cluster (cluster 11, genes MicB006_3113 to MicB006_3122). Besides six genes encoding NRPSs and PKSs, the BGC also contains a gene encoding a putative ClpC ATPase, indicating that the gene cluster may encode a ClpC-targeting antibiotic (Figure 3). A basic local alignment search tool (BLAST) ${ }^{35}$ search and subsequent phylogenetic analysis revealed nine genes encoding putative Clp subunits in the genome of strain B006, i.e., three ClpP proteases (MicB006_0681, MicB006_3937, and MicB006_3938), one ClpX subunit (MicB006_3936), one ClpB subunit (MicB006_0157), as well as four potential ClpC ATPases (MicB006_1895, MicB006_4945, MicB006_3122, and MicB006_6016). Thus, this BGC meets the requirements of target-directed genome mining, that is, it contains an extra copy of a housekeeping gene in association with natural product biosynthetic genes.

\section{Cloning and promoter replacement}

The 25.7-kb BGC (genes MicB006_3113 to MicB006_3122) appeared transcriptionally silent under our culture conditions. ${ }^{34}$ In order to activate its expression and to obtain the encoded compound, we cloned the entire BGC directly from the genomic DNA of Micromonospora sp. B006 by TAR cloning in yeast using the vector pCAP03- $a c c(3) I V^{\urcorner}$to yield pJB007EL (Figure 1a). The obtained plasmid was confirmed by restriction digest (Figure 1b).

To ensure transcription in the S. coelicolor heterologous host, we then replaced the native promoter with the ermE $E^{* 6,27}$ constitutive promoter using $\lambda$-Red-mediated recombination ${ }^{28-30}$ to generate pJB023EL (Figure 2a). Obtained clones were confirmed by restriction digest (Figure 2b).

Heterologous expression of the ClpC-containing BGC leads to induction of a host metabolite

S. coelicolor M1152 has been optimized by Gomez-Escribano and $\mathrm{Bibb}^{36}$ for heterologous expression 


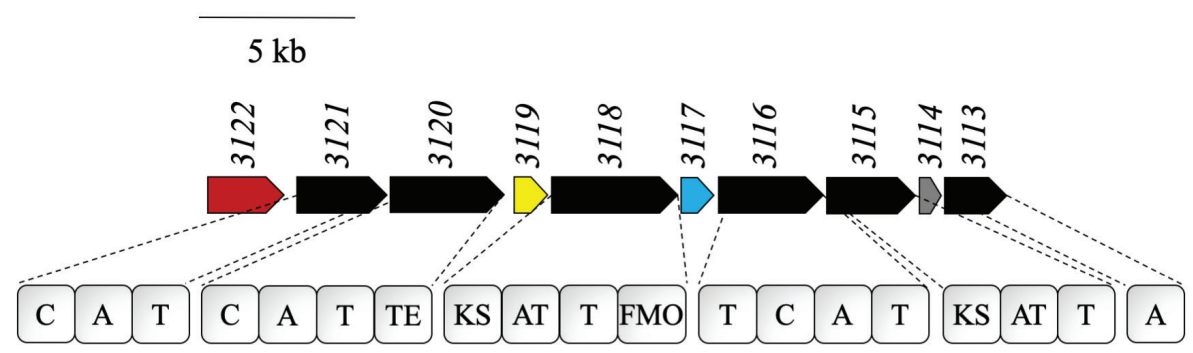

Gene key

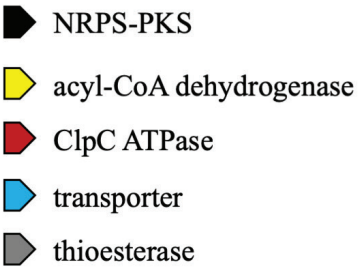

Domain key

$\begin{array}{ll}\text { A: } & \text { adenylation } \\ \text { C: } & \text { condensation } \\ \text { AT: } & \text { acyltransferase } \\ \text { FMO: } & \text { Flavin-dependent monooxygenase } \\ \text { KS: } & \text { ketosynthase } \\ \text { T: } & \text { thiolation } \\ \text { TE: } & \text { thioesterase }\end{array}$

Figure 3. ClpC-containing biosynthetic gene cluster from Micromonospora sp. B006. Genes (arrows) are color-coded according to predicted function.

of natural product BGCs and was therefore chosen as host for our experiments. Plasmid pJB023EL was transferred into $S$. coelicolor M1152 by conjugation from E. coli ET12567/pUZ8002. ${ }^{23}$ Mutants were confirmed by PCR. We then compared the metabolite profile of parent and mutant strains grown in CDM. A distinct peak at $30.8 \mathrm{~min}$ was observed in the mutants at a wavelength of $410 \mathrm{~nm}$ (Figure 4a). Upon closer inspection, this peak can be detected in the parent strain as well, although only as a trace compound.

The obtained UV-Vis spectrum of the peak with absorbance maxima at 334, 406, 536, and $572 \mathrm{~nm}$ showed high similarity to the UV-Vis spectrum of Zn coproporphyrin III available in our UV library (Figure 4a). Porphyrins are a class of photoactive molecules with a broad range of bioactivity. ${ }^{37}$ They are widely used in photodynamic therapies. ${ }^{38}$ The ability to produce porphyrins was reported for several Streptomyces spp..$^{37,39,40}$ Mass spectrometry analysis using liquid chromatography quadrupole (LCQ) showed an $\mathrm{m} / \mathrm{z}$ of 407 for the induced

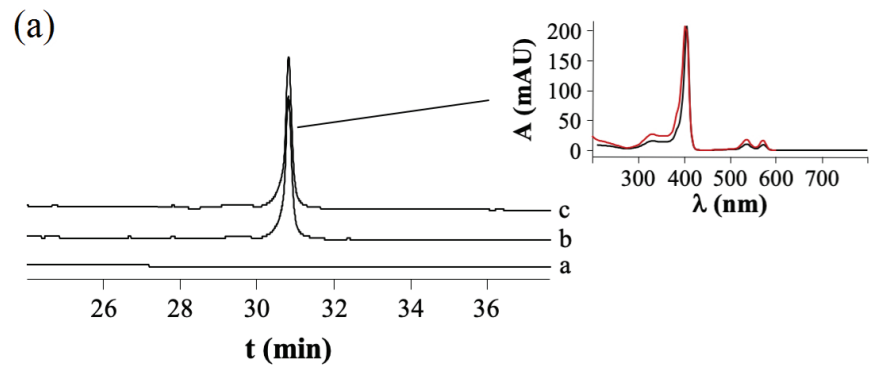

compound, which appears doubly charged (Figure 4b). The isotope pattern indicates that no zinc is bound. The observed mass does not match $\mathrm{Zn}$ coproporphyrin III (calcd. for $\mathrm{C}_{36} \mathrm{H}_{36} \mathrm{~N}_{4} \mathrm{O}_{8} \mathrm{Zn}$ : 716.182) or coproporphyrin III (calcd. for $\mathrm{C}_{36} \mathrm{H}_{38} \mathrm{~N}_{4} \mathrm{O}_{8}$ : 654.269). A search in the Global Natural Products Social Molecular Networking (GNPS) ${ }^{41}$ led to no hits. A manual comparison of the obtained $\mathrm{m} / \mathrm{z}$ with those of known porphyrins also led to no matches. We hypothesize that the induced compound may be an analog of known porphyrins. However, its structure remains to be determined.

\section{Transcriptional analysis}

Since we were unable to obtain the product of the NRPS-PKS gene cluster, we next analyzed gene transcription. Transcript analysis of four genes of the hybrid NRPS-PKS gene cluster, MicB006_3113, MicB006_3116, MicB006_3120, and MicB006_3122, revealed that only the gene encoding the putative ClpC ATPase was transcribed,

(b)

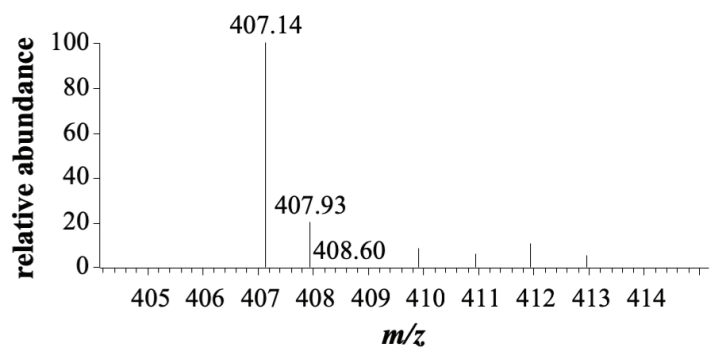

Figure 4. Heterologous expression. (a) HPLC analysis of culture extracts from parent strain S. coelicolor M1152 and from mutant strains (mt 2 and mt 7). The UV-Vis spectrum of the induced compound (black) was compared to Zn coproporphyrin III (red); (b) mass spectrometry analysis. Maximum intensity: $1.25 \times 10^{7}$. The spectrum shown is from $\mathrm{mt}$. The same $\mathrm{m} / \mathrm{z}$ is found in the parent strain as well. 
which indicates that only this gene is functional in our heterologous system (Figure 5).

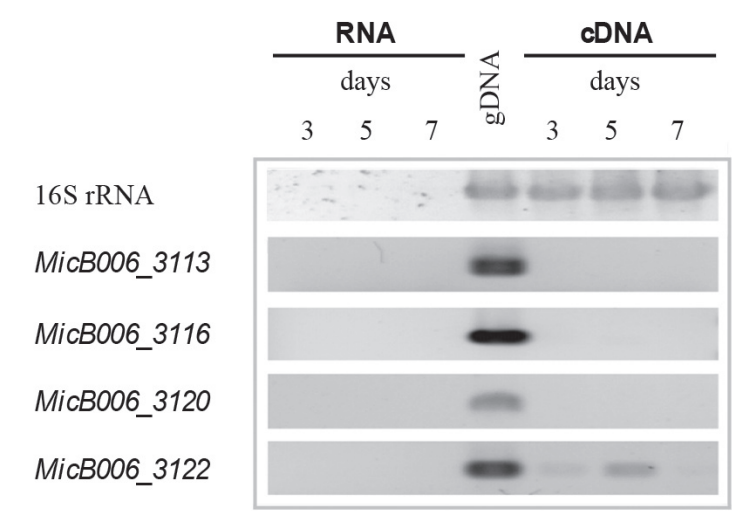

Figure 5. Transcriptional analysis. Reverse transcription PCR analysis of $S$. coelicolor containing pJB023EL grown in CDM medium.

Recent data support the idea that Clp ATPases could be involved in the activation of transcription. ${ }^{42}$ In addition, ClpA, a ClpC homolog in gram-negative bacteria, performs an ATP-dependent chaperone function independent of ClpP. ${ }^{43}$ It has been shown to remodel bacteriophage P1 RepA dimers into monomers, thereby activating the latent specific DNA binding activity of RepA. ${ }^{43}$ In Bacillus subtilis, $\mathrm{ClpC}$ is involved in the switch that controls the activity of a competence-specific transcription factor (ComK). ${ }^{44}$ ComK activates transcription of itself and other genes required for competence. When $\mathrm{ClpC}$ and $\mathrm{MecA}$, which confers specific molecular recognition, bind to ComK in the presence of ATP, it results in the inhibition of ComK DNA binding. ComS, a small protein required for ComK biosynthesis, can resolve this ternary complex by interacting with MecA. ${ }^{44} \mathrm{MecA}$ and ClpC also positively regulate autolysin gene expression in a similar way in which they affect competence. ${ }^{45}$ Here the effect is mediated through the sigma-D factor (SigD) protein instead of the ComK protein. ${ }^{45}$

Thus, our transcriptional analysis results combined with literature data suggest that expression of the ClpC gene is responsible for the induction of the host metabolite.

\section{Conclusions}

Freshwater Actinobacteria remain underexplored as a source of natural products. Resistance-gene-directed genome mining is a promising approach to discover bioactive compounds. ${ }^{7,9}$ In aiming to apply a resistancegene-directed approach for antibiotic discovery from freshwater Actinobacteria, we selected an NRPS-PKS BGC from a Lake Michigan Micromonospora sp. that contained a $\mathrm{ClpC}$ gene as a putative resistance gene. $\mathrm{ClpC}$ is an emerging anti-tuberculosis target. The $c l p C 1$ gene of M. tuberculosis is predicted to be necessary for the survival of the organism. ${ }^{46}$ The recently discovered antibiotics cyclomarin A, lassomycin, and ecumicin interact with ClpC $1^{17-20}$ and show potent activity against multidrugresistant M. tuberculosis strains. ${ }^{17,18,20,22}$

Although heterologous expression of the ClpC-containing BGC in S. coelicolor M1152 did not lead to the production of the encoded compound, we unexpectedly observed induction of a host metabolite. This is interesting and intriguing to us because firstly, we are not aware of reported instances of host metabolite induction when attempting BGC heterologous expression. Secondly, since a significant proportion of BGCs identified in microbial genomes are silent, methods to activate expression and allow compound identification are of interest. Our results suggest that ClpC chaperone expression may lead to gene activation. We are currently working on elucidating the structure of the induced host metabolite, on investigating the mechanism of induction, and on engineering the BGC further to try and obtain the encoded compound.

\section{Acknowledgments}

We thank Jessica Cleary and Laura Sanchez for help with MS analysis. Financial support for this work was provided by the National Center for Advancing Translational Sciences, National Institutes of Health (NIH), under grant KL2TR002002 (to A. S. E.) and by startup funds from the Department of Medicinal Chemistry and Pharmacognosy and the Center for Biomolecular Sciences, University of Illinois at Chicago (to A. S. E.). The content is solely the responsibility of the authors and does not necessarily represent the official views of the NIH.

\section{References}

1. Newman, D. J.; Cragg, G. M.; J. Nat. Prod. 2016, 79, 629.

2. Bentley, S. D.; Chater, K. F.; Cerdeno-Tarraga, A. M.; Challis, G. L.; Thomson, N. R.; James, K. D.; Harris, D. E.; Quail, M. A.; Kieser, H.; Harper, D.; Bateman, A.; Brown, S.; Chandra, G.; Chen, C. W.; Collins, M.; Cronin, A.; Fraser, A.; Goble, A.; Hidalgo, J.; Hornsby, T.; Howarth, S.; Huang, C. H.; Kieser, T.; Larke, L.; Murphy, L.; Oliver, K.; O’Neil, S.; Rabbinowitsch, E.; Rajandream, M. A.; Rutherford, K.; Rutter, S.; Seeger, K.; Saunders, D.; Sharp, S.; Squares, R.; Squares, S.; Taylor, K.; Warren, T.; Wietzorrek, A.; Woodward, J.; Barrell, B. G.; Parkhill, J.; Hopwood, D. A.; Nature 2002, 417, 141.

3. Udwary, D. W.; Zeigler, L.; Asolkar, R. N.; Singan, V.; Lapidus, A.; Fenical, W.; Jensen, P. R.; Moore, B. S.; Proc. Natl. Acad. Sci. U. S. A. 2007, 104, 10376. 
4. Ziemert, N.; Alanjary, M.; Weber, T.; Nat. Prod. Rep. 2016, 33, 988.

5. Rutledge, P. J.; Challis, G. L.; Nat. Rev. Microbiol. 2015, 13, 509.

6. Baltz, R. H.; J. Ind. Microbiol. Biotechnol. 2010, 37, 759.

7. Tang, X.; Li, J.; Millan-Aguinaga, N.; Zhang, J. J.; O’Neill, E. C.; Ugalde, J. A.; Jensen, P. R.; Mantovani, S. M.; Moore, B. S.; ACS Chem. Biol. 2015, 10, 2841.

8. Alanjary, M.; Kronmiller, B.; Adamek, M.; Blin, K.; Weber, T.; Huson, D.; Philmus, B.; Ziemert, N.; Nucleic Acids Res. 2017, 45, W42.

9. Yan, Y.; Liu, Q.; Zang, X.; Yuan, S.; Bat-Erdene, U.; Nguyen, C.; Gan, J.; Zhou, J.; Jacobsen, S. E.; Tang, Y.; Nature 2018 , 559,415

10. Munita, J. M.; Arias, C. A.; Microbiol. Spectrum 2016, 4, VMBF-0016-2015.

11. Steffensky, M.; Mühlenweg, A.; Wang, Z.-X.; Li, S.-M.; Heide, L.; Antimicrob. Agents Chemother. 2000, 44, 1214.

12. Kale, A. J.; McGlinchey, R. P.; Lechner, A.; Moore, B. S.; ACS Chem. Biol. 2011, 6, 1257.

13. Malik, I. T.; Brotz-Oesterhelt, H.; Nat. Prod. Rep. 2017, 34, 815.

14. Olivares, A. O.; Baker, T. A.; Sauer, R. T.; Nat. Rev. Microbiol. 2016, 14, 33.

15. Brotz-Oesterhelt, H.; Sass, P.; Int. J. Med. Microbiol. 2014, 304, 23.

16. Zolkiewski, M.; Mol. Microbiol. 2006, 61, 1094.

17. Schmitt, E. K.; Riwanto, M.; Sambandamurthy, V.; Roggo, S.; Miault, C.; Zwingelstein, C.; Krastel, P.; Noble, C.; Beer, D.; Rao, S. P.; Au, M.; Niyomrattanakit, P.; Lim, V.; Zheng, J.; Jeffery, D.; Pethe, K.; Camacho, L. R.; Angew. Chem., Int. Ed. Engl. 2011, 50, 5889 .

18. Gavrish, E.; Sit, C. S.; Cao, S.; Kandror, O.; Spoering, A.; Peoples, A.; Ling, L.; Fetterman, A.; Hughes, D.; Bissell, A.; Torrey, H.; Akopian, T.; Mueller, A.; Epstein, S.; Goldberg, A.; Clardy, J.; Lewis, K.; Chem. Biol. 2014, 21, 509.

19. Bürstner, N.; Roggo, S.; Ostermann, N.; Blank, J.; Delmas, C.; Freuler, F.; Gerhartz, B.; Hinniger, A.; Hoepfner, D.; Liechty, B.; Mihalic, M.; Murphy, J.; Pistorius, D.; Rottmann, M.; Thomas, J. R.; Schirle, M.; Schmitt, E. K.; ChemBioChem 2015, 16, 2433.

20. Gao, W.; Kim, J. Y.; Anderson, J. R.; Akopian, T.; Hong, S.; Jin, Y. Y.; Kandror, O.; Kim, J. W.; Lee, I. A.; Lee, S. Y.; McAlpine, J. B.; Mulugeta, S.; Sunoqrot, S.; Wang, Y.; Yang, S. H.; Yoon, T. M.; Goldberg, A. L.; Pauli, G. F.; Suh, J. W.; Franzblau, S. G.; Cho, S.; Antimicrob. Agents Chemother. 2015, 59, 880.

21. Culp, E.; Wright, G. D.; J. Antibiot. 2017, 70, 366.

22. Schultz, A. W.; Oh, D. C.; Carney, J. R.; Williamson, R. T.; Udwary, D. W.; Jensen, P. R.; Gould, S. J.; Fenical, W.; Moore, B. S.; J. Am. Chem. Soc. 2008, 130, 4507.
23. Kieser, T.; Bibb, M. J.; Buttner, M. J.; Chater, K. F.; Hopwood, D. A.; Practical Streptomyces Genetics; The John Innes Foundation: Norwich, 2000.

24. Kouprina, N.; Larionov, V.; Nat. Protoc. 2008, 3, 371.

25. Lõoke, M.; Kristjuhan, K.; Kristjuhan, A.; BioTechniques 2011 , 50,325 .

26. Bibb, M. J.; Janssen, G. R.; Ward, J. M.; Gene 1985, 38, 215.

27. Myronovskyi, M.; Luzhetskyy, A.; Nat. Prod. Rep. 2016, 33, 1006.

28. Datsenko, K. A.; Wanner, B. L.; Proc. Natl. Acad. Sci. U. S. A. 2000, 97, 6640.

29. Murphy, K. C.; Campellone, K. G.; Poteete, A. R.; Gene 2000, 246, 321.

30. Yu, D.; Ellis, H. M.; Lee, E. C.; Jenkins, N. A.; Copeland, N. G.; Court, D. L.; Proc. Natl. Acad. Sci. U. S. A. 2000, 97, 5978.

31. Gust, B.; Challis, G. L.; Fowler, K.; Kieser, T.; Chater, K. F.; Proc. Natl. Acad. Sci. U. S. A. 2003, 100, 1541.

32. Steffensky, M.; Li, S. M.; Heide, L.; J. Biol. Chem. 2000, 275, 21754.

33. Kominek, L. A.; Antimicrob. Agents Chemother. 1972, 1, 123.

34. Braesel, J.; Crnkovic, C. M.; Kunstman, K. J.; Green, S. J.; Maienschein-Cline, M.; Orjala, J.; Murphy, B. T.; Eustaquio, A. S.; J. Nat. Prod. 2018, 81, 2057.

35. U.S. National Library of Medicine (NLM), National Center for Biotechnology Information (NCBI); Basic Local Alignment Search Tool (BLAST); NLM/NCBI, USA, 2018.

36. Gomez-Escribano, J. P.; Bibb, M. J.; Microb. Biotechnol. 2011, 4, 207.

37. Martinez, A. F. C.; Almeida, L. G.; Moraes, L. A. B.; Consoli, F. L.; BMC Microbiol. 2017, 17, 143.

38. Ferreira, D. P.; Conceição, D. S.; Calhelha, R. C.; Sousa, T.; Socoteanu, R.; Ferreira, I.; Ferreira, L. F. V.; Carbohydr. Polym. 2016, $151,160$.

39. Musilek, V.; Science 1962, 137, 674.

40. Sato, K.; Shimizu, S.; Fukui, S.; Agric. Biol. Chem. 1968, $32,1$.

41. Wang, M.; Carver, J. J.; Phelan, V. V.; Sanchez, L. M.; Garg, N.; Peng, Y.; Nguyen, D. D.; Watrous, J.; Kapono, C. A.; LuzzattoKnaan, T.; Porto, C.; Bouslimani, A.; Melnik, A. V.; Meehan, M. J.; Liu, W. T.; Crusemann, M.; Boudreau, P. D.; Esquenazi, E.; Sandoval-Calderon, M.; Kersten, R. D.; Pace, L. A.; Quinn, R. A.; Duncan, K. R.; Hsu, C. C.; Floros, D. J.; Gavilan, R. G.; Kleigrewe, K.; Northen, T.; Dutton, R. J.; Parrot, D.; Carlson, E. E.; Aigle, B.; Michelsen, C. F.; Jelsbak, L.; Sohlenkamp, C.; Pevzner, P.; Edlund, A.; McLean, J.; Piel, J.; Murphy, B. T.; Gerwick, L.; Liaw, C. C.; Yang, Y. L.; Humpf, H. U.; Maansson, M.; Keyzers, R. A.; Sims, A. C.; Johnson, A. R.; Sidebottom, A. M.; Sedio, B. E.; Klitgaard, A.; Larson, C. B.; Boya P, C. A.; Torres-Mendoza, D.; Gonzalez, D. J.; Silva, D. B.; Marques, L. M.; Demarque, D. P.; Pociute, E.; O’Neill, E. C.; Briand, E.; Helfrich, E. J. N.; Granatosky, E. A.; Glukhov, E.; Ryffel, F.; Houson, H.; Mohimani, H.; Kharbush, J. J.; Zeng, Y.; Vorholt, J. 
A.; Kurita, K. L.; Charusanti, P.; McPhail, K. L.; Nielsen, K. F.; Vuong, L.; Elfeki, M.; Traxler, M. F.; Engene, N.; Koyama, N.; Vining, O. B.; Baric, R.; Silva, R. R.; Mascuch, S. J.; Tomasi, S.; Jenkins, S.; Macherla, V.; Hoffman, T.; Agarwal, V.; Williams, P. G.; Dai, J.; Neupane, R.; Gurr, J.; Rodriguez, A. M. C.; Lamsa, A.; Zhang, C.; Dorrestein, K.; Duggan, B. M.; Almaliti, J.; Allard, P. M.; Phapale, P.; Nothias, L. F.; Alexandrov, T.; Litaudon, M.; Wolfender, J. L.; Kyle, J. E.; Metz, T. O.; Peryea, T.; Nguyen, D. T.; VanLeer, D.; Shinn, P.; Jadhav, A.; Muller, R.; Waters, K. M.; Shi, W.; Liu, X.; Zhang, L.; Knight, R.; Jensen, P. R.; Palsson, B. O.; Pogliano, K.; Linington, R. G.; Gutierrez, M.; Lopes, N. P.; Gerwick, W. H.; Moore, B. S.; Dorrestein, P. C.; Bandeira, N.; Nat. Biotechnol. 2016, 34, 828.
42. Burton, B. M.; Baker, T. A.; Protein Sci. 2005, 14, 1945.

43. Pak, M.; Wickner, S.; Proc. Natl. Acad. Sci. U. S. A. 1997, 94 , 4901.

44. Turgay, K.; Hamoen, L.; Venema, G.; Dubnau, D.; Genes Dev. 1997, 11, 119.

45. Rashid, M. H.; Tamakoshi, A.; Sekiguchi, J.; J. Bacteriol. 1996, $178,4861$.

46. Kar, N. P.; Sikriwal, D.; Rath, P.; Choudhary, R. K.; Batra, J. K.; FEBS J. 2008, 275, 6149.

Submitted: August 14, 2018

Published online: December 3, 2018 